\title{
МЕСТО СТАРОДУБСКИХ РЮРИКОВИЧЕЙ В СЛУЖИЛОМ СОСЛОВИИ МОСКОВСКОГО ГОСУДАРСТВА ВТОРОЙ ТРЕТИ ХVI В.
}

\section{THE PLACE OF STARODUB RURIKOVICH IN THE SERVICE CLASS OF THE MOSCOW STATE IN THE SECOND THIRD OF THE $16^{\text {TH }}$ CENTURY}

A. Sergeev

Summary: The Article is devoted to determining the degree of participation in political events, the nature of land ownership of the Starodub Rurikovich, finding out the number and social status of surnames. It is established that in the first half of the XVI century, most of the princes of Starodubsky occupied a low position in the official and social hierarchy. The social status of the surnames of this branch changed back to seniority in the "pedigree ladder". Almost all Starodubsky rurikovichi kept land connections with the "family nest".

Keywords: princes of Starodub, social status, service, land ownership, mestnichestvo, sovereign's court.
$\mathrm{H}$ астоящая статья продолжает исследование малоизученной ветви Стародубских Рюриковичей, различные аспекты истории которых были рассмотрены в предыдущих публикациях автора [28], [29], [31], [33], [35]. В данной работе предпринята попытка определить место князей Стародубских в служилом сословии Московского государства второй трети XVI в. Необходимо отметить наиболее важные исследования историков, касающиеся данной темы. Родословные и биографии князей Пожарских, Ковровых рассматривались в трудах Л.М. Савелова, сохраняющих значимость, несмотря на то что вышли они более 100 лет назад [26], [27]. «Фамильный портрет в родовом интерьере и социополитическом аспекте» князей Ромодановских в первой-второй третях XVI в. детально разработал В.Д. Назаров [16]. Недавно отечественная историческая наука обогатилась первой полной научной биографией «спасителя отечества» в годы Смуты - князя Дмитрия Михайловича Пожарского [39]. Специальные работы были посвящены еще трем Пожарским: сподвижникам Д.М. Пожарского князьям Дмитрию и Роману Петровичам [10] и павшему в битве под Конотопом князю Семену Романовичу [3]. Жизнь и деятельность воевод XVII в. Семена и Никиты Никитичей Гагариных изучал Я.Н. Рабинович [20]. Политическое развитие и структуры землевладения Стародубского уезда в XIII-XVI вв. исследованы М.И. Давыдовым [8]. Князьям Татевым посвящена работа Н.В. и Э.В. Фроловых [38]. Накопленный материал дает возможность охарактеризовать место Стародубских княжеских фамилий в слу-

\author{
Сергеев Антон Вадимович \\ К.и.н., Санкт-Петербургский институт истории РАН \\ sergeev1967@inbox.ru
}

Аннотация: Статья посвящена определению степени участия в политических событиях, характера землевладения Стародубских Рюриковичей, выяснению численности, социального статуса фамилий. Установлено, что в первой половине XVI в. большинство князей Стародубских занимали невысокое положение в служебной и общественной иерархии. Социальный статус фамилий этой ветви менялся обратно старшинству в «родословной лествице». Почти все Стародубские Рюриковичи сохраняли поземельные связи с «родовым гнездом».

Ключевые слова: князья Стародубские, социальный статус, служба, землевладение, местничество, Государев двор.

жилом сословии Московского государства второй трети XVI в. Предшествующий период их истории изучен А.А. Зиминым [9, с. 35-43]. Указанная проблема рассматривается ниже в следующих аспектах: состав «территориального объединения» князей Стародубских; влияние «Тысячной реформы» 1550 г. на их положение; военная и административная деятельность князей в рассматриваемый период; местнические конфликты с их участием.

Из Стародубской ветви Рюриковичей в конце XV первой половине XVI в. выделилось 15 фамилий [23, c. 58-85].

Две из них (Осиповские и Небогатые) угасли до 1550 г., а остальные указаны ниже в Табл. 1. В левом столбце отмечены князья, внесенные в Тысячную книгу (далее - ТК), в правом - в Дворовую тетрадь (далее - ДТ). Табл. 1 составлена с использованием реконструкции утраченной части Стародубского «Княжеского списка» ДТ (далее - СКС) [33, с. 42-46]. Лица, выделенные полужирным курсивом, записаны в сохранившемся тексте, а про отмеченных простым курсивом известно, что они находились на службе в 1550-х гг., владели вотчинами в «родовом гнезде» и, следовательно, могли числиться в этом памятнике. Принятая за основу при реконструкции СКС гипотеза А.П. Павлова, поддержанная А.Л. Корзининым, о ДТ как «расширенном списке» Государева двора, включавшем не только лиц, входивших в его состав, но и «потенциально» пригодных к службе в нем [12, с. 23-24], 
обусловила включение в Табл. 1 почти полного состава Стародубской ветви Рюриковичей, исключая князей умерших, вышедших из службы к началу 1550-х гг., а также слишком молодых, в службу «не поспевших» недо- рослей.

Сведения ДТ и других памятников позволяют установить состав территориального княжеского объеди-

Князья Стародубские в ТК и дт ${ }^{1}$

\begin{tabular}{|c|c|c|c|}
\hline № & Князья Стародубские & Тысячная книга & Дворовая тетрадь \\
\hline 1. & Дмитрий Федорович Щереда Палецкий & - & Боярин \\
\hline 2. & Дмитрий Иванович Хилков & Статья 1. Стародуб & Окольничий, боярин \\
\hline 3. & Давыд Федорович Палецкий & Статья 1. Кострома & Окольничий \\
\hline 4. & Пожарский Иван Иванович Большой & - & CKC \\
\hline 5. & Пожарский Михаил Иванович Столб & - & CKC \\
\hline 6. & Пожарский Иван Иванович Меньшой & - & CKC \\
\hline 7. & Пожарский Федор Иванович Меньшого & - & CKC \\
\hline 8. & Пожарский Яков Иванович & - & CKC \\
\hline 9. & Пожарский Борис Федорович Долгий & - & CKC \\
\hline 10. & Пожарский Василий Федорович Медведь & - & CKC \\
\hline 11. & Пожарский Тимофей Федорович & Статья 3. Стародуб & CKC \\
\hline 12. & Пожарский Петр Борисович Корова & Статья 3. Стародуб & CKC \\
\hline 13. & Пожарский Петр Тимофеевич Щепа & - & CKC \\
\hline 14. & Пожарский Иван Васильевич Черный & Статья 3. Стародуб & CKC \\
\hline 15. & Пожарский Борис Васильевич Белобок & - & CKC \\
\hline 16. & Пожарский Тимофей Васильевич & - & CKC \\
\hline 17. & Пожарский Михаил Васильевич & - & CKC \\
\hline 18. & Пожарский Петр Васильевич & Статья 3. Стародуб & CKC \\
\hline 19. & Пожарский Семен Борисович & - & CKC \\
\hline 20. & Пожарский Михаил Борисович & - & CKC \\
\hline 21. & Пожарский Федор Иванович Третьяков & Статья 3. Стародуб & CKC \\
\hline 22. & Пожарский Иван Иванович Третьяков & Статья 3. Стародуб & CKC \\
\hline 23. & Кривоборский Иван Александрович & - & CKC \\
\hline 24. & Кривоборский Андрей Иванович & - & CKC \\
\hline 25. & Кривоборский Василий Иванович & - & CKC \\
\hline 26. & Кривоборский Иван Иванович & - & CKC \\
\hline 27. & Кривоборский Федор Иванович & - & CKC \\
\hline 28. & Кривоборский Василий Иванович Меньшой & - & CKC \\
\hline 29. & Ковров Василий Иванович & Статья 3. Стародуб & CKC \\
\hline 30. & Ковров Иван Семенович & - & CKC \\
\hline 31. & Ковров Иван Андреевич & Статья 3. Стародуб & CKC \\
\hline 32. & Ковров Осип Андреевич & Статья 3. Стародуб & CKC \\
\hline 33. & Ковров Петр Андреевич & - & CKC \\
\hline 34. & Ромодановский Богдан (Сава) Петрович & - & CKC \\
\hline
\end{tabular}

$[37$, с. $54,55,57,58,63,65,67,77,80,83,99,111-113,123,125,128,188,195,197,201]$. В Табл. 1 учтены важные биографические пометы, отсутствующие в изданном тексте ДТ, но сохранившиеся в неопубликованных списках этого памятника (ОР ГИМ. Музейское собрание № 3417. Сборник разрядно-родословный; ОР РНБ. Ф. 487. Собрание Н.М. Михайловского. Ғ. 162. Л. 51-51 об.). 


\begin{tabular}{|c|c|c|c|}
\hline № & Князья Стародубские & Тысячная книга & Дворовая тетрадь \\
\hline 35. & Ромодановский Андрей Васильевич Нагаев & Статья 2. Стародуб & - \\
\hline 36. & Ромодановский Михаил Петрович & - & CKC \\
\hline 37. & Ромодановский Афанасий Андреевич Нагаев & - & CKC \\
\hline 38. & Ромодановский Василий Андреевич Нагаев & - & CKC \\
\hline 39. & Ромодановский Федор Борисович & Статья 2. Стародуб & CKC \\
\hline 40. & Ромодановский Иван Борисович & Статья 3. Стародуб & CKC \\
\hline 41. & Ромодановский Михаил Борисович & & CKC \\
\hline 42. & Ромодановский Петр Меньшой Борисович & Статья 3. Стародуб & CKC \\
\hline 43. & Стригин-Ряполовский Михаил Иванович & - & CKC \\
\hline 44. & Татев Петр Иванович & Статья 2. Стародуб & CKC \\
\hline 45. & Татев Андрей Иванович & Статья 3. Стародуб & CKC \\
\hline 46. & Татев Федор Иванович & Статья 3. Стародуб & CKC \\
\hline 47. & Гундоров Семен Иванович & Статья 2. Стародуб & CKC \\
\hline 48. & Гундоров Иван Иванович Гордой & - & CKC \\
\hline 49. & Гундоров Федор Андреевич & Статья 3. Стародуб & CKC \\
\hline 50. & Гундоров Иван Андреевич & Статья 3. Стародуб & CKC \\
\hline 51. & Гундоров Александр Андреевич & - & CKC \\
\hline 52. & Гундоров Данило Федорович & Статья 3. Стародуб & CKC \\
\hline 53. & Гундоров Роман Иванович & - & CKC \\
\hline 54. & Гундоров Иван Григорьевич & - & CKC \\
\hline 55. & Гундоров Никита Григорьевич & - & CKC \\
\hline 56. & Гундоров Сила Григорьевич & - & CKC \\
\hline 57. & Тулупов Данило Иванович & - & CKC \\
\hline 58. & Палецкий Семен Дмитриевич & - & CKC \\
\hline 59. & Палецкий Василий Дмитриевич & - & CKC \\
\hline 60. & Палецкий Федор Дмитриевич & - & CKC \\
\hline 61. & Палецкий Андрей Дмитриевич & - & CKC \\
\hline 62. & Палецкий Борис Дмитриевич & - & CKC \\
\hline 63. & Стародубский-Льяловский Семен Иванович & Статья 2. Москва & \\
\hline 64. & & Москва & \\
\hline 65. & $\begin{array}{l}\text { Стародубский-Льяловский Никита Михайло- } \\
\text { вич }\end{array}$ & Статья 3. Москва & \\
\hline 66. & & Москва & \\
\hline 67. & Стародубский-Льяловский Андрей Иванович & - & Москва \\
\hline 68. & Ромодановский Антон Михайлович & Статья 3. Москва & Москва \\
\hline 69. & Ромодановский Иван Михайлович & - & Москва \\
\hline 70. & Гагарин Иван Посник Федорович & Статья 3. Тверь & Тверь \\
\hline 71. & Гагарин Петр Федорович & - & Тверь \\
\hline 72. & Гагарин Владимир Иванович & - & Клин \\
\hline 73. & Гагарин Федор Курака Васильевич & - & Клин \\
\hline 74. & Гагарин Данило Юрьевич & Статья 3. Вязьма & Вязьма \\
\hline 75. & Гагарин Юрий Юрьевич & Статья 3. Вязьма & Вязьма \\
\hline
\end{tabular}




\begin{tabular}{|c|c|c|c|}
\hline № & Князья Стародубские & Тысячная книга & Дворовая тетрадь \\
\hline 76. & Гагарин Дмитрий Шемяка Данилович & Статья 3. Вязьма & Вязьма \\
\hline 77. & Гагарин Иван Данилович & Статья 3. Вязьма & Вязьма \\
\hline 78. & Гагарин Андрей Семейка Данилович & Статья 3. Вязьма & Вязьма \\
\hline 79. & Гагарин Федор Данилович & - & Вязьма \\
\hline 80. & Гагарин Дмитрий Юрьевич & - & Вязьма \\
\hline 81. & Гагарин Андрей Юрьевич & - & Вязьма \\
\hline 82. & Гагарин Иван Юрьевич & - & Вязьма \\
\hline 83. & Гагарин Иван Дмитриевич & - & Вязьма \\
\hline 84. & Гагарин Федор Дмитриевич & - & Вязьма \\
\hline 85. & Гундоров Иван Васильевич & - & Вязьма \\
\hline 86. & Гундоров Федор Васильевич & - & Вязьма \\
\hline 87. & Гундоров Давыд Васильевич & Статья 3. Вязьма & Вязьма \\
\hline 88. & Гундоров Андрей Иванович & - & Вязьма \\
\hline 89. & Тулупов Владимир Иванович & - & Вязьма \\
\hline 90. & Гагарин Семен Иванович & Статья 3. Дмитров & - \\
\hline 91. & Гагарин Иван Семенович & - & Дмитров \\
\hline 92. & Гагарин Федор Семенович & - & Дмитров \\
\hline 93. & Ромодановский Иван Федорович & - & Бежецкий Верх \\
\hline 94. & Ромодановский Никита Иванович & - & Бежецкий Верх \\
\hline 95. & Ромодановский Константин Иванович & - & Бежецкий Верх \\
\hline \multirow[t]{3}{*}{96.} & Гагарин Владимир Иванович & Статья 2. Гдов & - \\
\hline & Тулупов Андрей Васильевич & Статья 1. Новгород & - \\
\hline & Тулупов Владимир Васильевич & Статья 1. Новгород & - \\
\hline
\end{tabular}

нения (далее - ТКО) Стародубских Рюриковичей. В него входили князья, владевшие землями в «родовом гнезде» и, как правило, несшие с них службу. Указанное ТКО просуществовало весь XVI в., постепенно сокращаясь вследствие пресечения отдельных фамилий [35, с. 82-85]. В середине XVI в. оно было одним из самых больших, уступая только князьям Ярославским и примерно равняясь Оболенским. В СКС ДТ отмечены князья 9 из 15 фамилий данной ветви Рюриковичей. Поскольку ДТ составлялась и велась с целью учета лиц, пригодных к службе в Государевом дворе, то запись в нее осуществлялась по месту расположения земельных владений, с которых несли службу князья, дворяне и дети боярские, или по чинам бояр, окольничих. Например, большинство князей Тулуповых служили с поместий, находившихся за пределами Стародубского уезда, но поземельные связи с «родовым гнездом» у них полностью не были потеряны [33, с. 41]. Таким образом, ТКО отличается от СКС более широким составом. Кроме указанных в СКС лиц в него следует включить князей, сохранявших поземельные связи с «родовым гнездом», но служивших с более крупных владений, находившихся в иных уездах или учтенных в ДТ не «по Стародубу», а в составе бояр, окольничих. В «родовом гнезде» большинству Стародубских Рюриковичей принадлежали сравнительно небольшие владения (от 100 до 600 четей (далее - ч.)). В писцовых книгах 1620x гг. зафиксированы крупные вотчинные комплексы у Хилковых (около 2000 ч.), ${ }^{2}$ Татевых (более 2000 ч.), ${ }^{3}$ Ромодановских (около 2500 ч.) ${ }^{4}$. Князья Палецкие обладали значительным числом вотчин и поместий, рассредоточенных по 8 уездам, но размер каждого владения не превышал 600-700 ч. Вероятно, подобным образом обстояло дело и у многих других фамилий. Объясняется отмеченный характер землевладения тем, что вследствие размножения большинства фамилий Стародубской ветви родовые вотчины делились на части и при отсутствии

2 РГАДА.Ф. 1209. ОП. 1. Кн. 11320. Л. 998 об.-1024.

3 РГАДА. Ф. 1209. Оп. 1. Кн. 11320. Л. 1083-1099 об. Этой вотчиной в 1620-х гг. владел стольник князь Федор Семенович Куракин, выкупившей ее «по родству... шурей его князя Федора и Ивана родовая вотчина Татевых».

4 РГАДА. Ф. 1209. Оп. 1. Кн. 11320. Л. 729 об.-735 об.; 782 об.-785; 820 о6.-825, 860-866 об., 1099 об.-1174, 1254 об.-1257 об., 1537 об. -1538 ०6. 
прямых наследников уходили в монастыри или другим фамилиям в качестве приданого за дочерьми, несмотря на то что иногда князьями практиковался их выкуп. При возникновении благоприятных обстоятельств князья приобретали земли в иных уездах через государственные пожалования, заключение брачных союзов, покупкой. Доходов с «родовых вотчин» хватало не всем, поэтому необходимым условием исправного несения службы были поместья, дававшиеся в разных районах государства. Так, в Боярской книге 1556 г. (далее - БК1556) про князя П.Б. Пожарского отмечено: «Вотчины за ним отца его пол-пол-полчетверти сохи, поместья 503 четверти... А лета 7060 четвертаго на Свияге ... поместья сказал на пол-200 четвертей, вотчины на 30 четвертей». Общий размер его земельных владений изначально составлял около 600 ч., большая часть их была поместной. Ко времени оформления БК1556 они сократились вдвое, до 300 ч. Размер вотчины князя Петра Васильевича Пожарского был 80 ч., а поместья - 200 ч. У князя Ивана Немого Пожарского общий размер владений достигал 400-600 ч. и большая часть была поместной (вотчинных - 130 ч.). Напротив, стольник «князь Иван княж Иванов сын Козловского Ромодановского» ${ }^{5}$ служил с вотчин, размер которых составлял около 1500 ч. [25, с. 88-90, 100]. Его владения могли находиться в Московском и Стародубском уездах, поскольку, с одной стороны, известно о наличии у князей этой фамилии вотчин в «родовом гнезде», а с другой - в ДТ некоторые числились «по Москве» $[16$, с. 60-62].

Социальный статус фамилий Стародубской ветви менялся обратно старшинству в «родословной лествице»: примерно одинаковый («второстепенный») имели Пожарские, Кривоборские, Льяловские, Ковровы, Осиповские. Князья этих фамилий не получали в XVI в. думных чинов, но исполняли разрядные назначения. Начиная с Ромодановских статус повышался, достигнув максимума у Палецких. Конечно, прямой зависимости нет. Так, Тулуповы «первенствовали» непродолжительное время в 1570-х гг, Гундоровы, не смотря на активную служебную деятельность и регулярное исполнение разрядных служб, думных чинов не удостоились, оставшись «второстепенными» князьями. Тем не менее, на протяжении XVI В. можно констатировать тенденцию роста социального статуса у младших фамилий Стародубских Рюриковичей.

«Тысячная реформа» 1550 г. предполагала приближение к Государеву двору наиболее способных лиц, в том числе «второстепенных» и «захудавших» князей, что должно было заметно улучшить их общественное положение. В ТК были включены князья почти из всех фамилий Стародубских Рюриковичей, кроме Кривоборских и угасших к этому времени Осиповских, Небогатых. Единственный из Кривоборских, служивших в 1550-х гг., князь Иван Александрович, вероятно, не попал в число «лучших слуг» по недостатку способностей или в силу иных причин, а его сыновья были еще слишком молоды. По замыслу реформы в «тысячники» принимались наиболее способные к исполнению служебных поручений князья. Возрастных категорий «лучших слуг» в Стародубской ветви можно условно выделить две: 20-летние и 40-летние. К младшей принадлежали князья, недавно вступившие на служебное поприще, но уже показавшие способности, а старшую составляли их родственники, приближавшиеся к «предельному возрасту пребывания на службе», но сохранявшие «форму», имевшие значительный послужной список и, в целом, хорошо зарекомендовавшие себя. К поколению, начавшему службу во втором-третьем десятилетия XVI в., принадлежали Дмитрий и Давыд Палецкие, Ф.Б., И.Б., П.Б. Ромодановские, С.И., Ф.А., И.А. Гундоровы, Т.Ф., И.В., П.В., Ф.И. И.И. Пожарские, С.И. Льяловский, Д.Ю., Ю.Ю., С.И. Гагарины (Табл. 1). Князь Дмитрий Палецкий родился в первые годы XVI в. (его отец князь Ф.И. Большой погиб в 1506 г.). Двоюродные братья Д. Палецкого, младшим из которых был Давыд, - не позднее 1514 г. (в этом году под Оршей был пленен их родитель - Федор Меньшой) [31, с. 45, 48-49]. Известно, что отец братьев Ромодановских Борис Васильевич тоже попал в плен в этой битве и не вернулся назад [2, с. 155, 162, 170], [9, с. 40]. Следовательно, сыновья у него родились до 1514 г. Одно из первых упоминаний источниками князя Тимофея Пожарского относится к 7027 (1518/19) г., когда он участвовал в разделе отцовской вотчины, получив на двоих с братом Иваном сельцо Троицкое с деревнями [1, с. 27-28]. Следовательно, оба они родились в первом-втором десятилетиях XVI в. и к 1550 г. Т. Пожарскому было около 40 лет. Для остальных князей примерный возраст может быть определен по месту в родословной. Соотношение старших и молодых князей, отобранных в «избранную тысячу», получилось близким - соответственно 17 и 19 чел.

Тот факт, что в «тысячники» были отобраны наиболее способные лица, подтверждается большим числом разрядных назначений в 1533-1566 гг. в сравнении с другими князьями соответствующих фамилий. Так, у

5 И.И. Ромодановский не записан в «Бархатной книге» и других родословных. В.Д. Назаров предположил, что в данном месте памятника допущена неточность в отчестве князя и речь шла об Иване Михайловиче [16, с. 60-62]. По-мнению А.Л. Корзинина это два разных лица [12, с. 157, 469]. В пользу решения, предложенного В.Д. Назаровым, можно указать три факта. Во-первых, прозвище «сын Козловского» указывает на князя Михаила Козлока Ромодановского. Во-вторых, Иван Иванович не мог быть его внуком, что легко усмотреть «по счету поколений» и известных биографических сведений об М.В. Козлоке и двух его сыновьях. Младший сын князя Михаила Иван (Табл. 1. № 67) родился не ранее середины 1520-х гг. (скорее всего, в 1530-х) и к 1556 г. вырастить взрослого сына никак не мог успеть. В-третьих, можно допустить, что отцом Ивана Ивановича был князь Иван Борисович или Иван Федорович (Табл. 1. №40, 91), но согласно «Бархатной книге» у них сыновей по имени Иван не было и пояснение «сын Козловского» указывает на старшую линию Ромодановских. 
Пожарских в рассматриваемый период разрядами упоминались только «тысячники». У Палецких - наиболее преуспевшие в служебном отношении князья Дмитрий и Давыд. Чаще ближайшей родни исполняли разрядные назначения Д.И. Хилков, А.В. Нагаев, А.М., Ф.Б., П.Б., И.Б. Ромодановские, П.И., Ф.И., А.И. Татевы, С.И., Ф.А., И.А. Д.В. Гундоровы, И.Ф., В.И., Д.Ю, Ю.Ю., Д.Д., И.Д., А.Д., С.И. Гагарины [21, с. 79-221, 554, 556, 574, 580, 583, 593]. Конечно, служебная карьера удалась не всем. Так, редко или вовсе не отмечались разрядами Д.Ф. Гундоров, В.И., И.А., О.И. Ковровы, С.И., Н.М. Льяловские. До начала 1570-х гг. не упоминались служившие с новгородских поместий А.В., В.В. Тулуповы.

Для испомещения «тысячников» были выделены Московский, часть Дмитровского, Звенигородский, Рузский уезды (расстояние от Москвы 60-70 верст) [37, с. 53]. В писцовых книгах 1550-х-1620-х гг. сохранились сведения о вотчинах и поместьях в Подмосковье и смежных уездах почти всех фамилий Стародубских Рюриковичей [15, с. 91-93], [24, с. 123-124, 158-159], [18, с. 1, 9, 10, 15, $21,23,24,27,28,35,36,40,43,45,69,115,116,139,156$, 164-165, 175, 176, 180, 228, 229, 230, 236, 258, 262, 331]. В указанных уездах у части князей имелись владения, приобретенные в первой половине XVI в., и им выделение поместий не предусматривалось ${ }^{7}$. Обеспеченность землями вблизи столицы Стародубских «тысячников» была высокой, но не «стопроцентной». Вероятно, земли достались не всем «тысячникам» из Гагариных, возможно, не получили поместий князья Ковровы. Конечно, отсутствие в писцовых книгах сведений о подмосковных владениях указанных лиц может объясняться также их неполнотой [36, с. 410-411].

Прибегать к большому перемещению землевладельцев соответствующих уездов для освобождения необходимых площадей под испомещение «тысячников» правительство, по-видимому, не планировало. Предполагалось выделить поместья только лицам, не имевшим владений вблизи столицы, по мере естественного освобождения занятых владений или образования новых. Реформа, таким образом, растягивалась на десятилетия. Скорее всего, она была осуществлена частично и после «активной фазы» в начале 1550-х гг. стала «затухать». На изменение подходов к ее реализации могло повлиять крупнейшее военное предприятие начала 1550-х гг. - завоевание Казанского ханства. Некоторые «тысячники» погибли в ходе сражений или умерли от полученных ран позднее. Из князей Стародубских в этот период «выбыл» А.В. Нагаев (Табл. 1. № 35). Оформленная в 1552-53 гг. ДТ отражает происшедшие изменения: «тысячники», «выбывшие из службы» между 1550-53 гг. в ней отсутствуют. Составление ТК и ДТ велось с противоположных позиций. Если для включения в первый памятник нужно было пройти строгий отбор и только наиболее способные лица записывались в него, то во второй включались все годные к службе в ближайшей перспективе. Составители ДТ стремились учесть не только князей, состоявших на государевой службе, но и «поспевавших» для нее новиков. Поэтому с отцами нередко указывались сыновья, с дядьями племянники, но малолетние «недоросли», родившиеся в 1550-х гг., как правило, не учитывались. Этим объясняется отсутствие в СКС ДТ младших сыновей в некоторых фамилиях и князей еще слишком молодых для службы (сыновья Д.И. Хилкова, А.И. Ряполовский и др.).

В ДТ «представлен» расширенный «выбор» с городов, находившихся в центре государства. В последующие десятилетия в Боярских списках отмечен почти тот же состав городов. Конечно, полного совпадения в перечне городов ДТ и Боярских списков нет, но в большей части оно имеет место быть, исключения требуют специального исследования, выходящего за рамки настоящей статьи ${ }^{8}$. Произошел ли в 1550-х гг. сознательный отказ от проведения «Тысячной реформы» и переход к модели «выбора с городов» определенно решить трудно из-за недостатка информации в источниках, но результат получился таким.

Отсутствие роста социального статуса у большинства «тысячников» из «захудавших» фамилий служит косвенным указанием на изменение первоначального плана реформы. В начале 1560-х гг. князья Пожарские, Кривоборские, Льяловские, Ковровы и др. остались примерно на том же уровне общественного положения, как в 1550 г. «Тысячники» старшего поколения в большинстве своем сошли с политической сцены в середине-конце 1550х гг. Судя по имеющимся данным на их место предусмотренный царским указом «прибор» не осуществлялся.

Основной сферой деятельности князей была военная служба. О ней сохранилось больше всего сведений в разрядных книгах, иных памятниках. О службах «гражданских» (наместничества, описания земель, посольские церемонии и др.) к исполнению которых князья также привлекались, до нас дошли отрывочные данные. В военные походы князья ходили во главе отрядов, численность которых зависела от размера вотчин и поместий. Так, в распоряжении князей П.Б. и П.В. Пожарских было всего по 3 человека, у И.И. Третьякова - 6, И. Ромоданов-

6 РГАДА. Ф. 1209. Оп. 1. Кн. 425. № 233. Л. 376, № 180. Л. 305, 611; Кн. 627. Л. 648-650 об.; Кн. 628. Л. 124-125, 198-202; Кн. 845. № 135; Кн. 9806. Л. 13, 15, 662-665.

7 «за которыми бояры и за детьми боярскими вотчины в Московском уезде или в ыном городе, которые блиско Москвы верст за 50 или за 60 и тем поместья не давати» [37, с. 54].

8 Отсутвие в ДТ городов Одоева, Вереи, Луха, Алексина объясняется тем, что в 1550-х гг. они находились в собственности князей В.А. Старицкого, Одоевских, Бельских. Уезды Шуйский, Кинешемский выделились из Суздальского только к началу XVII в. 
ского - 15. Князья, проявившие военные и административные способности назначались наместниками в города, становились полковыми, городовыми воеводами или возглавляли всю рать в том или ином военном походе.

Ограничение на объем публикации не позволяет подробно рассмотреть военные, административные, дипломатические службы Стародубских Рюриковичей, поэтому ниже отмечены только источники, содержащие указанные сведения по отдельным фамилиям, и эти данные учтены в итоговых выводах статьи.

В соответствии с отмеченным выше ростом социального статуса и служебной активности фамилий Стародубских Рюриковичей от старших к младшим чаще других разрядами второй трети XVI в. отмечались назначения Д. Палецкого, его двоюродного брата Давыда, Д.И. Хилкова [13, с. 142, 686-688], [19, с. 41], [21, с. 104, $110,112,125,131,135-137,141,143,144,156,160,163$, $172,181,192,194],[37$, с. 114], Ромодановских [5, с. 49, 77], $[6$, c. 63-64], [16, c. 60, 67-69, 70-72], [17, c. 52], [21, c. 10, 11, $92,104-107,110,119,123,124,125,131,138,152,159,174$, $177,190,207-209,211,215,245,256,271,273,296],{ }^{10}$ Гундоровых, И. Осиповского [21, с. 99, 102, 105, 109, 112, 113, $117]^{11}$, Татевых [5, с. 77], [17, с. 52], [21, с. 59, 68, 70, 74-76, $78,79,81,83,84,87,88,90,91,122-123,128,131,143,144$, $150,151,155,157,161,162,164,165,178-180,185-187$, 195, 200, 202- 205, 207, 214, 217-219, 222, 223, 225, 229, $229,230],[22, \text { c. } 191-195]^{12}$.

Князья остальных фамилий (Льяловские, Стригины, Гагарины, Тулуповы) занимали более скромные должности [21, с. 110, 111, 121, 125, 155, 176, 197, 199, 218].

В рассматриваемый период князья Пожарские, ${ }^{13}$ Кривоборские, Ковровы воеводами не назначались. Они, возглавляя своих «боевых холопов», состояли «в полку» вместе с другими служилыми людьми. В подобных случаях не было почвы для местнических конфликтов, но данные службы не фиксировались разрядами.

Нередко князья руководили работами по описаниям земель. В 1555-68 гг. А.И. Стародубский Льяловский, Д.Д. Гагарин, И.Б., П.Б., Н.И. Ромодановские, Ф.И. Меньшого Пожарский, И.В. Гундоров описывали Московский, Переславский, Юрьевский, Устюжский уезды, Заонежские погосты Обонежской пятины [16, с. 71-73], [11].

Место Стародубских среди других князей характери- зуют местнические конфликты. В рассматриваемый период известно 8 местнических «случаев» у Стародубских Рюриковичей $[40$, с. 47, 50, 52, 54, 55]. Почти все они описаны в разрядных книгах [21, с. 144, 194-195, 217, 220], [22, с. 135, 145-146, 191-196] кроме столкновения 1557 г. между князьями П.И. Татевым и М.П. Репниным на воеводстве в Курске. О нем известно из описания царского архива, где хранилось «Дело князя Михаила Репнина со князем Петром Татевым», которое могло быть и не местническим [7, с. 482-483], [40, с. 52]. В указанных конфликтах участвовали князья из фамилий «растущего» социального статуса (Д. Щереда, Д. Хилков, П.И., Ф.И. А.И. Татевы). Напротив, у князей, общественное положение которых оставалось неизменным, подобных столкновений не зафиксировано [30, с. 312].

\section{$* * *$}

В первой половине XVI в. Стародубские Рюриковичи занимали невысокое положение в служебной и общественной иерархии. В ТК и ДТ они были записаны после Оболенских, Ростовских, Суздальских, Ярославских, но выше Мосальских и Белозерских Рюриковичей. Отступление от указанного порядка записи случилось лишь однажды. В сопровождавшей в Новгородском походе Ивана III 1495 г. свите князья Стародубские были записаны после Суздальских, но прежде Ростовских и Ярославских [21, с. 24-26]. Это нарушение последовательности, принятой в позднейших документах, можно объяснить политическим весом, который Стародубские приобрели благодаря деятельности князей Ряполовских [35, с. 8283]. Разрядные назначения показывают, что даже наиболее видным и способным князьям Стародубской ветви редко доводилось возглавлять отдельные полки, не говоря уже о командовании целым войском. Обычно они исполняли должности вторых, третьих воевод, наместничали в небольших пограничных городах. Наместничество Д. Палецкого в Великом Новгороде - единственное исключение [31, с. 48]. В разрядных росписях и местнических конфликтах князья Стародубские «бессловно» признавали старшинство Воротынских, Одоевских, потомков Гедимина (Голицыных, Щенятевых, Мстиславских, Бельских), старших фамилий в ветви князей Оболенских (Курлятевых, Телепневых) и Ярославских (Троекуровых, Курбских), всех фамилий Суздальских Рюриковичей, но были старше младших князей Ярославских - Охлябининых, Хворостининых, Прозоровских, Сицких. Они пытались местничаться с Хованскими, но без особого успеха. Отмеченное положение Стародубских Рюриковичей

9 Военная и административная деятельность князей Палецких рассмотрена автором в специальной статье [31].

10 Указания на боярский чин Ф.Б. Ромодановского в работах А.А. Зимина и Р.Г. Скрынникова ошибочны [16, с. 69]. Согласно помете в ДТ князь К.И. Ромодановский «Умре в Казани» [37, с. 201]. В начале XVI В. окольничим был В.В. Ромодановский, но боярство его брата Ивана Телеляша не подтверждено сведениями надежных источников [19, с. 13, 16, 18].

11 Отдел рукописей РГБ. Ф. 304/III. № 25. Л. 204 об.

12 Отдел рукописей РГБ. Ф. 304/ІІІ. № 25. Л. 92, 95 об.

13 Деятельность Пожарских рассмотрена автором в специальной работе [29]. 
было обусловлено, в значительной степени, их последним местом в «родословной лествице» потомков Всеволода Большое Гнездо. Социальный статус большинства фамилий князей Стародубских оставался стабильным, у некоторых имелся «потенциал» к его повышению, но реализовать его удалось в последних десятилетиях XVIXVII вв. только Ромодановским и Пожарским.

Ветвь князей Стародубских во второй трети XVI в. была одной из крупнейших в роду Рюриковичей - в ее составе было более 100 князей. Почти все способные к службе князья этой ветви были включены в ТК и ДТ (Табл. 1). Эти памятники показывают высокую степень вовлеченности в службу Стародубских Рюриковичей. Крупнейшей фамилией были Гагарины, но именно они меньше остальных представлены в ТК и ДТ. Объясняется это утратой ими связей с «родовым гнездом» и переходом многих на службу с поместий отдаленных Северо-Западных уездов (Новгородского, Псковского). Из примерно 40 лиц указанных в «Бархатной книге» в соответствующих поколениях, в ТК и ДТ записаны только 19. Многочисленными были фамилии Пожарских, Гундоровых. Малочисленностью отличались Льяловские, Кривоборские, Ковровы, Ряполовские, Тулуповы. Перечисленные фамилии угасли в последних десятилетиях XVI - начале XVII в. Пресечение Палецких было следствием гибели многих из них на войнах.

Социальный статус большинства Стародубских Рюриковичей был «второстепенным» (не имели думных чинов, но исполняли разрядные службы). В относительном «закоснении» находились отдельные линии Гагариных, Небогатые. Во второй трети XVI в. «первостепенный» статус и лидирующие позиции в ветви Стародубских Рюриковичей заняли самые младшие в «родословной лествице» Палецкие, началось возвышение Хилковых и Татевых. В значительной мере эти успехи объяснялись способностями Д.Ф. Щереды, Д.И. Хилкова, П.И. Татева, активной службой других князей указанных фамилий. По-видимому, недостаток таких деятелей среди Ромодановских, Гундоровых, Пожарских не позволил им повысить статус в рассматриваемый хронологический период.

Сведений о брачных союзах Стародубских Рюриковичей немного. Наиболее известен брак княжны Ульяны Палецкой с братом Ивана Грозного Юрием Васильевичем. Сестра (неизвестно родная или двоюродная) Д.Ф. Щереды была женой окольничего В.П. Бороздина. Обычно браки заключались между княжескими и нетитулованными фамилиями равного социального статуса. Так, супругой П. Пожарского была княжна Федосия Семеновна Мезецкая. Эта фамилия владела землями в Старо- дубском уезде, имела второстепенный статус. Отец Д.М. Пожарского был женат на обеспеченной представительнице Беклемишевых. Подобным был брачный союз князя Д. Небогатого с Е. Левашовой и др. [32, с. 340-341]

Княжеский титул позволял повысить общественный статус «захудавшим» фамилиям при появлении благоприятных обстоятельств. Кроме того, брачный союз между представительницами зажиточных нетитулованных фамилий и «закосневшими» князьями давал первым титул и приращение социального статуса, а вторым предоставлял возможность улучшить материальное положение, необходимое для успеха служебной карьеры. В дальнейшем князь мог передать потомкам «приданую вотчину» жены, как было у Пожарских, наследовавших владения Беклемишевых. Конечно, не всегда эта возможность могла реализоваться. Так, князь Д. Небогатый вследствие ранней кончины не смог сделать служебной карьеры, брак с Е. Левашовой оказался бездетным. Второе замужество Ефросинии не состоялось, и вотчина Левашовых перешла Иосифо-Волоколамскому монастырю в обеспечение спасения душ близких княгини ${ }^{14}$. В последних десятилетиях XVI в. княжеский титул стал одним из факторов роста социального статуса многих «закосневших» князей.

Во второй трети XVI в. в служилом сословии Московского государства около половины княжеских фамилий отличались от других служилых людей не только титулом, но пребыванием в составе особых ТКО. Выделение некоторых, наиболее значительных из них в ДТ и других памятниках свидетельствует о признании их правительством. В число последних входило ТКО Стародубских Рюриковичей.

Несмотря на сравнительно низкий социальный статус большинства Стародубских Рюриковичей во второй трети XVI в. этот период можно рассматривать как наиболее благоприятный не только для них, но также иных княжеских фамилий. О процветании свидетельствует многочисленность княжеских родословных в поколениях, живших в это время. Другим показателем является значительное число денежно-вещевых вкладов, данных князьями в монастыри [34, с. 132-143].

Начало Ливонской войны в конце 1550-х гг., учреждение опричнины в 1565 г. привели к неблагоприятным, кризисным переменам в судьбе многих княжеских фамилий, немало их угасло (в Стародубской ветви - Палецкие, Тулуповы, Ряполовские, Льяловские), существенно ухудшилось положение остальных. Тем не менее, уцелевшие князья сохранили владения в Стародубском уезде, но рассмотреть процессы, происходившие в этот период, автор надеется в другой статье.

14 Согласно дате на надгробной плите, княгиня Е. Небогатая скончалась 23 октября 1552 г. в Новодевичьем монастыре [4, с. 117]. 


\section{ЛИТЕРАТУРА}

1. Акты Суздальского Спасо-Евфимьева монастыря 1506-1608 гг. / Сост. С.Н. Кистерев, Л.А. Тимошина. М., 1998.

2. Антонов А.В., Кром М.М. Списки русских пленных в Литве первой половины XVI века. // Архив русской истории. М., 2002. Вып.7. С. 149-196.

3. Бабулин И.Б. Князь Семен Пожарский и Конотопская битва. СПб., 2009.

4. Беляев Л.А., Григорян С.Б., Шуляев С.Г. Некрополь Смоленского собора Новодевичьего монастыря XVI-XVII в. исследования 2017-2018 г.: методы и результаты // Древняя Русь. Вопросы медиевистики. 2019. № 4 (78). С. 112-127.

5. Вкладная книга Троице-Сергиева монастыря. М., 1987.

6. Вкладныя и записныя книги Иосифова Волоколамскаго монастыря XVI века.. . // Титов А.А. Рукописи славянския и русския, принадлежащия И.А. Вахрамееву. Вып. V. М., 1906. С. 63-64.

7. Государственный архив России XVI столетия: Опыт реконструкции / Подгот. текста и коммент. А.А. Зимина. [Вып. 3]. М., 1978.

8. Давыдов М. И. Стародуб Ряполовский в XIII - 70-х гг. XVI в.: политическое развитие, административно-территориальное устройство, эволюция структур землевладения. Дисс. канд. историч. наук.: 07.00.02. Владимир, 2004.

9. Зимин А.А. Формирование боярской аристократии во второй половине XV-первой трети XVI века. М., 1988.

10. Кабанов А.Ю., Семененко А.М. Ивановский край в Смутное время. Иваново, 2010.

11. Каталог писцовых описаний Русского государства середины XV - начала XVII века / Сост. К.В. Баранов. М., 2015. [Электронный ресурс]. Адрес доступа: (http://rgada.info/materiali/baranov_catalog.pdf) http://srch.slav.hokudai.ac.jp/jcrees/20130saka/14Zaytsevs.pdf(дата обращения: 26.01.2020).

12. Корзинин А.Л. Государев двор Русского государства в доопричный период (1550-1565гг.). М.; СПб., 2016.

13. Курбский А.М. История о делах великого князя Московского / подгот. К. Ю. Ерусалимский. М., 2015.

14. Лисейцев Д.В., Рогожин Н.М., Эскин Ю.М. Приказы Московского государства XVI-XVII вВ.: словарь-справочник. М.; СПб., 2015.

15. Материалы для истории Звенигородского края. Вып. 1. М., 1992

16. Назаров В.Д. Князья Ромодановские в эпоху становления Российского централизованного государства // Государев двор в истории России XV-XVII столетий. Материалы международной научно-практической конференции. Владимир, 2006. С. 32-84.

17. Назаров В.Д. 0 структуре «Государева двора» В середине XVI в. // Общество и государство феодальной России. М., 1975. С. 40-54.

18. Писцовые книги книги Московского государства. Писцовые книги XVI века / Под ред. Н.В. Калачева. СПб., 1872. Ч. 1. Отд. 1.

19. Послужной список старинных Бояр и Дворецких, Окольничих и некоторых других придворных чинов. . . // Древняя Российская Вивлиофика. М., 1791. Ч. XX.C. 1-131.

20. Рабинович Я.Н. Братья Семен и Никита Гагарины: страницы биографии (1610-1640). Саратов, 2015.

21. Разрядная книга $1475-1598$ гг. М., 1966.

22. Разрядная книга $1475-1605$ гг. Т. 2. Ч. 1. М., 1982.

23. Родословная книга князей и дворян российских и выезжих..., которая известна под названием Бархатной книги. М., 1787. Ч. 2. М., 1787.

24. Рузский уезд по писцовой книге 1567-1569 годов. М., 1997.

25. Русский дипломатарий. М., 2004. Вып. 10.

26. Савелов Л.М. Князья Ковровы // Сборник статей в честь М. К. Любавского. Пг., 1917. С. 286-296.

27. Савелов Л.М. Князья Пожарские // Летопись Историко-родословного общества в Москве. Вып. 2-3. М., 1906. С. 5-88.

28. Сергеев А.В. Князья Гагарины в Русском государстве XVI - XVII вв. // Вспомогательные исторические дисциплины в современном научном знании: Материалы XXXII Международной научной конференции. Москва, 11-12 апр. 2019 г. М., 2019. С. 362-364.

29. Сергеев А.В. Князья Пожарские в Русском государстве XVI - XVII вВ.: политическая деятельность и землевладение. // Клио. 2018 . № 9 (141). С. 75 -87.

30. Сергеев А.В. Местнические конфликты княжеских фамилий Московского государства XVI-XVII вB.: динамика и тенденции // Русь, Россия: Средневековье и Новое время. Выпуск 5: Пятые чтения памяти академика РАН Л.В. Милова. Материалы к международной научной конференции. Москва, 9-10 ноября 2017 г. М., 2017. С. 308-313.

31. Сергеев А.В. Политическая деятельность и землевладение княжеской аристократии Московского государства XVI в.: князья Палецкие. // Древняя Русь. Вопросы медиевистики. 2019. № 3 (77). С. 43-59.

32. Сергеев А.В. Представители княжеских фамилий Московского государства XVI-XVII веков во вкладных книгах Иосифо-Волоколамского монастыря // Преподобный Иосиф Волоцкий и его обитель: Сб. статей. Вып. 4. М.: Добрая мысль, 2017. С. 326-374.

33. Сергеев А.В. Стародубские Рюриковичи в Тысячной книге 1550 г. и Дворовой тетради начала 1550-х гг. // Клио. 2018. № 8 (140). С. 36 -48.

34. Сергеев А.В. Троице-Сергиев монастырь и княжеская аристократия Московского государства в XVI-XVII в.: виды и динамика вкладов // Троице-Сергиева Лавра в истории, культуре и духовной жизни России: материальные свидетельства духовной культуры. Сборник материалов IX международной конференции 16-17 октября 2014 года. Сергиев Посад, 2016 г. С. 132-143.

35. Сергеев А.В. Эволюция территориальных княжеских объединений Суздальских и Стародубских Рюриковичей в конце XV-XVI вв. // Русь, Россия: Средневековье и Новое время. Выпуск 6: Шестые чтения памяти академика РАН Л.В. Милова. Материалы к международной научной конференции. Москва, 21-22 ноября 2019 г. (Труды исторического факультета МГУ: Вып. 163. Сер. ІІ. Исторические исследования: 102). М., 2019. С. $82-86$.

36. Смирнов И.И. Очерки политической истории русского государства 30-50-х гг. XVI в. М.; Л.,1958. 
37. Тысячная книга 1550 г. и Дворовая тетрадь 50-х годов XVI в. М.; Л., 1950.

38. Фролов Н.В., Фролова Э.В. Стародуб на Клязьме и князья Татевы-Стародубские. Ковров, 2017.

39. Эскин Ю.М. Дмитрий Михайлович Пожарский. М., 2013.

40. Эскин Ю. М. Местничество в России XVI-XVII вв. Хронологический реестр. М., 1994.

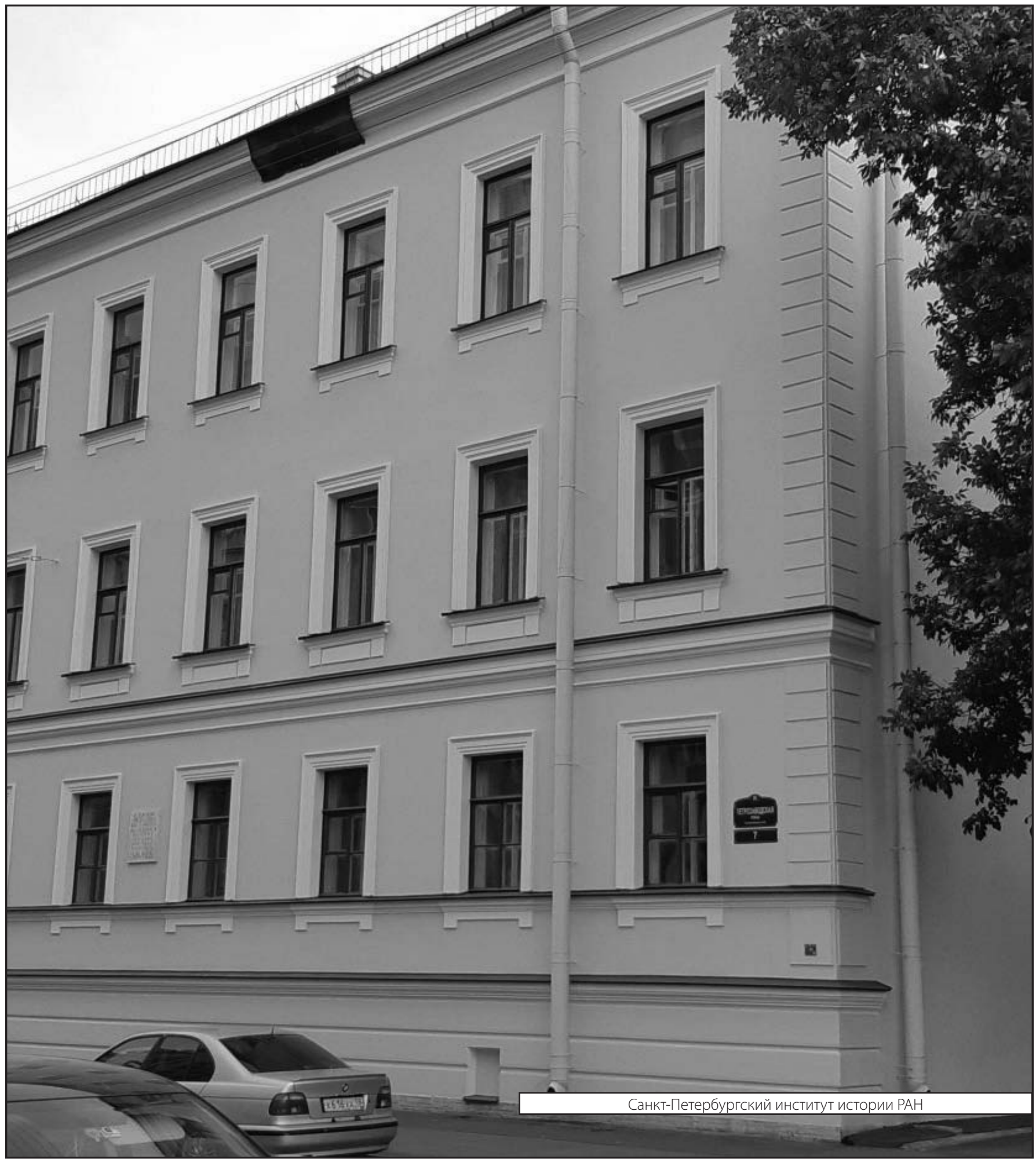

